\title{
La función hermenéutica de la obra literaria en Cómo se hace una novela
}

\section{The hermeneutic function of the literary work in Cómo se hace una novela}

\author{
Gastón BERALDI \\ (Universidad de Buenos Aires)
}

Recibido: 6/09/2011

Aceptado: 19/03/2013

\section{Resumen}

El objetivo de este trabajo es dar cuenta de la fecundidad que el pensamiento de Unamuno (1864-1936) presenta en torno al problema hermenéutico. Para ello se tomará como eje la obra Cómo se hace una novela (1926-7), donde el pensador bilbaíno expone sus ideas en torno a la cuestión de la escritura y la recepción de la obra literaria. El estudio de la obra en cuestión y la referencia a muchas de sus otras obras estará atravesado por las nociones que acuñara Ricoeur de "distanciamiento" y "apropiación" del mundo del texto. La importancia que cobra en Unamuno el receptor de la obra, anticipándose a las ulteriores teorías de la recepción, nos lleva a ver qué entiende éste por "comprensión", y cuál es el papel que esa noción juega en sus concepciones filosófico-literarias. Finalmente, a partir de este "distanciamiento" y "apropiación" de la obra que propone Unamuno al lector, le será posible al receptor, la proyección de un mundo.

Palabras clave: hermenéutica, Unamuno, texto, mundo.

\begin{abstract}
The purpose of this work is realize of the fecundity that Unamuno's (18641936) thought presents concerning the hermeneutic problem. For it the work will take as a point of item Cómo se hace una novela (1926-7), where Unamuno exposes his ideas concerning the question of the writing and the receipt of the literary work. The study of the work in question and the reference too many of his other works will be crossed by the notions that there was coining Ricoeur of "distancing"
\end{abstract}


and "appropriation" of the world of the text. The importance that takes in Unamuno the receiver of the work, being anticipated to the subsequent theories of the receipt, leads us to seeing what deals this one for "comprehension", and which is the role that this notion plays in his philosophical - literary conceptions. Finally, from this "distancing" and "appropriation" of the work that Unamuno proposes to the reader will be possible to the receiver, the projection of one world.

Keywords: Hermeneutic, Unamuno, Text, World.

\section{Introducción}

Este trabajo propone dar cuenta de la fecundidad que el pensamiento de Unamuno presenta en torno al problema hermenéutico. Para ello se tomará como eje la obra Cómo se hace una novela donde el pensador bilbaíno expone sus ideas en torno a la cuestión de la escritura y la recepción de la obra literaria, especialmente en este caso, la novela. El estudio de la obra en cuestión y la referencia a varias de sus otras obras estará atravesado por las nociones que acuñara Ricoeur de "distanciamiento" y "apropiación" del mundo del texto. Sin embargo, antes se hace necesario también dar cuenta de la importancia que cobra en Unamuno el receptor de la obra, anticipándose a las ulteriores teorías de la recepción.

Asimismo, las líneas teóricas de una teoría de la recepción en Unamuno nos llevan a ver qué entiende éste por "comprensión", y cuál es el papel que esa noción juega en sus concepciones filosófico-literarias. Finalmente, a partir de este "distanciamiento" y "apropiación" de la obra que propone Unamuno al lector, le será posible al receptor, proyectar un mundo.

De esta manera, nuestra indagación tratará de responder: a) ¿qué lugar ocupa la obra literaria y, la novela en particular, en el pensamiento de Unamuno?; b) ¿cuál es el lugar en que Unamuno posiciona al receptor/lector?; c) ¿qué entiende nuestro autor por “comprensión”?; d) ¿es posible dar cuenta de una función hermenéutica, desde el punto de vista de la filosofía, de la obra literaria en el pensamiento unamuniano?

\section{El lugar de la obra literaria en el pensamiento de Unamuno}

La cuestión del lugar que ocupa la obra literaria en el pensamiento de Unamuno, nos lleva en primer lugar a preguntarnos, qué entiende él por "obra literaria". Sin embargo, cualquier respuesta que se estime dar a esta última cuestión se nos escurre entre las manos. Unamuno no es un hombre de definiciones. Las conceptualiza- 
ciones no le son de su agrado, y en "Novela, ensayo, estudio" incluso llega a sostener que "[...] toda novela es un ensayo...y si me apura un poco le diré que todo ensayo es un novela." " La indefinición lo lleva en ciertos momentos hasta la identidad o proximidad entre géneros como la autobiografía, la historia, la novela y la poesía, proximidad que incluso hacen de la novela, política. ${ }^{2}$ La vaguedad y ambigüedad con que Unamuno usa el lenguaje permite desplegar toda la potencialidad semántica que se encuentra en una palabra, en una frase, en un párrafo, en un texto.

El lenguaje unamuniano aparece repleto de figuras literarias: metáforas, alegorías, símiles, mitos, paradojas, antítesis, hipérboles. Para Unamuno, las palabras delimitadas encorsetan las vivencias, empobrecen la riqueza enorme de los conocimientos intuitivos, racionalizan lo que de suyo es irracional. Por eso, el recurso empleado por él, junto con otros vitalistas, consiste en valerse de figuras literarias con el fin de empujar poco a poco al lector para que él a su vez sienta y descubra vivencias semejantes. ${ }^{3}$

El problema de la relación lenguaje-realidad cobra en Unamuno un sentido particular. Todos los sentimientos humanos como el amor, el odio, la admiración y la tristeza, y todos aquellos en que el tema a expresar es más hondo, menos materialidad debe tener el vehículo que los expresa. Unamuno acude a la poesía o a la narrativa para exponer su más hondo y sublime deseo. ${ }^{4}$ Por ello afirma que:

[...] Para expresar un sentimiento o un pensamiento que nos brota desde las raíces del alma, tenemos que expresarlo con el lenguaje del mundo, tomando del mundo, de la sociedad que nos rodea, los elementos que dan consistencia, cuerpo y verdura a ese follaje $[\ldots]^{5}$

Porque un lenguaje racional, con unos términos cuyo significado ha sido definido y delimitado, encierra un mensaje cerrado, completamente elaborado. El lector, en ese caso, se comporta como un receptor pasivo al que se le cierran las alas de la imaginación. En cambio la vaguedad del lenguaje poético permite que el lector contribuya a precisar el mensaje, a cooperar en la búsqueda, a crear un espacio hermenéutico en que es necesario que el lector interprete.

\footnotetext{
1 Unamuno, M. de: "Novela, ensayo, estudio", en Manuel García Blanco (ed.), Obras Completas, Madrid, Editorial Escélicer, Vol.VII, 1966, p. 881

2 Cfr. Unamuno, M. de: Cómo se hace una novela, Buenos Aires, Alba, 1927, pps. 47; 64-65; 69-70 y 77.

3 Padilla Novoa, M.:Unamuno: filósofo de encrucijada, Bogotá, Cincel, 1985, pp. 40-41

4 Gómez Miranda, R.: "Cinco puntos clave del pensamiento de Unamuno", en Horizonte, Bello Horizonte, V. 4, Nº7, 2005, p. 58

5 Unamuno, M. de: "El secreto de la vida", en Obras Completas, Op. cit., Vol. III, 1966, p. 879.
} 
López Molina sostiene que lo que hace Unamuno es una crítica a la racionalidad científica desde las claves que proporciona la experiencia estética. ${ }^{6}$ El problema fundamental en Unamuno es el de la vida y su sentido, y como él mismo sostiene "[...] todo lo vital es irracional y todo lo racional es antivital [...]"7 Siendo así que la vida es antes que la razón -como él mismo ha dicho en reiteradas ocasiones-, aquella deberá manifestarse mediante métodos apropiados que no pueden ser los de la exposición deductiva, sino los de la expresividad propia de la Estética. Sin embargo, la estética como forma de expresión en Unamuno, no es una pura estética de recreación, sino que tiene en su origen un para qué vital.

\subsection{El lugar de la novela en el pensamiento de Unamuno}

De todos los modos de expresión que se encuentran en la obra unamuniana, la novela, o mejor, la nivola como a él más gusta en llamarle, es el más constante y significativo ya que representa un procedimiento muy valioso para sus lucubraciones filosóficas. Las novelas desempeñan el papel de proyectar la conciencia hacia fuera. El texto novelesco en la obra de Unamuno es, como sostiene Marcos, adecuada representación filosófica una vez constatada la limitación de la representación conceptual para expresar su filosofía. De esta manera, es la materialización en la que más adecuadamente se realiza la dramatización consciente de la vida. ${ }^{8}$ Es un reflejarse a uno mismo, un desnudarse ante el lector y ante sí mismo. En esta proyección de la conciencia, los conceptos se convierten en personas; " " [...] los conceptos tienen, como los hombres, vida interior y dramática y alma; un concepto es una persona ideal y llena de historia e intrahistoria [...]"10 La novela se convierte en laboratorio de la vida, en instrumento de investigación, en vehículo de intuiciones. ${ }^{11}$ A través de ella intenta traspasar la capa de lo fenoménico para acceder a la auténtica realidad que para él es algo inaccesible a la razón.

El lugar que Unamuno otorga a la novela como vehículo de expresión a lo largo de su obra y pensamiento es sumamente manifiesto en este fragmento:

\footnotetext{
${ }^{6}$ López Molina, A.: “Introducción”, en Unamuno, M. de: Del sentimiento trágico de la vida, Madrid, Biblioteca Nueva, 2006, p. 20

7 Unamuno, M. de: Del sentimiento trágico de la vida, Madrid, Biblioteca Nueva, 2006, p. 138.

8 Cfr. Marcos, L.A.: Miguel de Unamuno: una filosofía hermenéutica española, Tesis Doctoral, Salamanca, Universidad de Salamanca, 1991, pp. 426-436.

9 Cfr. Unamuno, M. de: Tres novelas ejemplares y un prólogo, Buenos Aires, Espasa Calpe, 1955, p. 18.

10 Unamuno, Miguel de: La regeneración del teatro español, en Obras Completas, Op. cit., I, pp. $903-$ 904.

11 Padilla Novoa, M.: Op. cit., p. 42-44 y Marcos, L.A.: Op. cit., p. 439.
} 
[...] Muy lejos de decaer el papel de la novela, ábresele a ésta cada vez nuevos y más amplios horizontes, y puede asegurarse que las novelas son hoy el canal más importante por donde llega al pueblo el pensamiento sociológico, ético, religioso y filosófico de los maestros. ${ }^{12}$

Pero la novela y el novelista unamunianos no se identifican con lo que entendemos tradicionalmente por el novelista o literato y la literatura. Unamuno pone una distancia crítica de estas nociones y no ahorra calificativos para quienes puedan inscribirse o inscriban su obra bajo estos rótulos. Recurre a un pasaje del Apocalipsis, del Libro de la Revelación, en que el Espíritu le manda al apóstol que se coma un libro, para sostener, entre otras cosas que "[...] esos mezquinos y menguados cotarros de los hombres de letras [...] ni saben amasar con su sangre y su carne un libro que se coma, ${ }^{13}$ sino escribirlo con tinta y pluma." 14 Esta crítica es la que está en la base de la distinción entre "novela" como género literario y nivola como novela.

Una novela para Unamuno es una auto-biografía, pero no como género literario, sino por cuanto uno pone su carne y su sangre para hacerla. ${ }^{15}$ Una novela verdadera consiste en decir cómo se hace y no cómo se cuenta. 16 " [...] Los novelistas que ahora hacen libros para explicar el mecanismo de su novela, para ver cómo ellos proceden a escribir, lo que hacen, sencillamente, es levantar la tapa del reloj." 17 Mientras que "[...] el novelista que cuenta como se hace una novela cuenta como se hace un novelista, o sea como se hace un hombre."18 De esta manera distingue el escribir una novela -como las que escriben los literatos-, de hacer una novela-que es tarea de novelistas.

Nuestro autor concibe al término "novela" en al menos tres sentidos muy diferentes, pero que sin embargo, se encuentran imbricados. Quizá podríamos arriesgar que uno de esos sentidos del término "novela" es, en término generales, el que caracteriza al género literario. Un segundo sentido es aquél al que Unamuno le otorga el neologismo de "nivola", ${ }^{19}$ pero una nivola no es cualquier novela, sino una de

12 Unamuno, M. de: "El porvenir de la novela" en Obras Completas, Op. cit., VIII, pp. 1282-1283.

13 Con la metáfora de "amasar con su sangre y con su carne un libro que se coma", Unamuno viene a cuestionar a quienes escriben sin sentirlo, a aquellos sin vocación de escritor. Ser escritor para Unamuno, como bien sentencia Cerezo Galán en Las máscaras de lo trágico..., supone una forma integral de ser hombre, la de existir en la palabra, por cuanto es hacer de la palabra la forma de la existencia. Así Unamuno concebirá su vocación de escritor como la respuesta a una llamada.

14 Unamuno, M. de: Cómo se hace una novela, Op. cit., p. 44.

15 Esas son expresiones unamunianas.

16 Ibid., p. 110.

17 Ibid., p. 146.

18 Ibid., p. 149.

19 Una definición de "nivola" la encontramos en el prólogo a la segunda edición de Amor y Pedagogía, más de treinta años después de su primera edición. Allí Unamuno las define como "Relatos dramáticos acezantes, de realidades íntimas, entrañadas, sin bambalinas ni realismos en que suele faltar la 
realidad íntima, real, eterna, agónica, de carne y hueso, poética, creativa. ${ }^{20}$ Un tercer sentido, quizá más fuerte, más vívido, más individual, más ontológico, y que está en directa relación con la nivola, donde la novela no confluye en un género, sino en una vida; porque quien escribe una nivola escribe su novela.

Pero detengámonos aquí en dos cuestiones: a) el uso que hace de verbo "contar" y b) la analogía mecánica-orgánica. ${ }^{21}$ En primer lugar, parecieran contradictorias las citas unamunianas si no advirtiéramos al lector que lo que parecen ser ciertas inconsistencias de su lenguaje, son ellas tan sólo aparentes. Unamuno en Cómo se hace una novela, pero también en el resto de su obra, escribe en varios niveles del lenguaje. Su relato de cómo se hace una novela es en realidad un metarrelato donde él describe cómo se hace una novela, haciendo la novela del lector de otra novela y haciendo la novela de su vida. El verbo "cuenta", en tercera persona del singular del presente del indicativo, lo utiliza con dos sentidos distintos en las notas que indicamos bajo los números 16 y 18, sin embargo, el "cómo se hace" de la nota 16 se corresponde con el "cuenta" de la 18, ya que para Unamuno, decir cómo se hace una novela, es describir y no explicar. 22

En segundo lugar, Unamuno afirma unas líneas más adelante de la cita referida, que la analogía del reloj es inapropiada, ya que responde a la idea del "mecanismo de su ficción". Pero una ficción de mecanismo, mecánica, no puede ser una novela, ya que una novela, para ser viva, tiene que ser organismo y no mecanismo declara, porque no hay maquinaria que mostrar, sino " [...] entrañas palpitantes de vida, calientes de sangre. Y eso se ve fuera."23 Escribir contando cómo se hace una novela es hacerla. Y se pregunta Unamuno si es algo más que una novela la vida de cada uno de nosotros, y por ende, si hay novela más novelesca que una auto-biografía. ${ }^{24}$

Esto nos lleva a indagar más detenidamente qué entiende Unamuno por "novela". En un pasaje de Cómo se hace una novela se pregunta qué es lo que hace él con

verdadera, la eterna realidad, la realidad de la personalidad". El término "nivola" es empleado por Unamuno para dar a entender que sus "novelas" no pretenden entrar de lleno a formar parte del "género" novelesco, y ni siquiera participar en la polémica de los géneros literarios. Este es otro de los motivos por los cuales es muy complejo dar cuenta de qué entiende Unamuno por "obra literaria" o "literatura". Así como no le agrada a él que lo encasillen, consecuentemente con ello, él tampoco encasilla, ni siquiera a su obra. Las referencias a este neologismo son explicitadas por él también en el prólogo de Tres novelas ejemplares y un prólogo, y al final del Cap. XVII de Niebla.

20 Cfr. Unamuno, M. de: Tres novelas ejemplares y un prólogo, Op. cit., ps. 9 y 12.

21 Considérese de especial relevancia que la distinción entre organicismo y mecanicismo se remonta a la disputa del Romanticismo -más cercano al pensamiento alemán- con la Ilustración, propia de los cartesianos y newtonianos.

22 Esta distinción entre describir y explicar recorre gran parte de la obra y el pensamiento unamunianos, especialmente en Del Sentimiento Trágico de la vida, donde se pueden encontrar las bases gnoseológicas y epistemológicas de su pensamiento.

23 Unamuno, M. de: Cómo se hace una novela, Op. cit., p. 147

24 Ibid., p. 47. Es preciso indicar que, para Unamuno, una autobiografía, la íntima de cada filósofo, que da cuenta de lo que tiene de hombre concreto, explica mucho más que su propia filosofía. 
la novela política y religiosa de su vida. Como dice Montesinos en el Quijote: “ipaciencia y barajar!”, ese es el problema. Pero a continuación le pide al lector que no se moleste porque le viene planteando problemas políticos y religiosos en vez de contarle, como le había prometido, cómo se hace una novela. Allí mismo le pregunta al lector si desea que se detenga "en esto del problema", y antes que nada responde diciendo:

[...] Dispensa a un filólogo helenista que te explique la novela, o sea la etimología, de la palabra problema. Que es sustantivo que representa el resultado de la acción de un verbo proballein que significa echar o poner por delante, presentar algo y equivale al latino proiicere, proyectar, de donde problema viene a equivaler proyecto. Y el problema, proyecto de qué es? De acción! [...] un problema presupone no tanto una solución, en el sentido analítico, o disolutivo, cuanto una construcción, una creación. Se resuelve haciendo. O dicho en otros términos un proyecto se resuelve en un trayecto, en un cambio. Y sólo con la acción se resuelve problemas. $[\ldots]^{25}$

La primera oración del fragmento citado es sumamente significativa. ¿Pide Unamuno al lector que lo exima de explicarle la novela? O ¿pide que se lo exima de explicarle la etimología de la palabra "problema"? El término "dispensa" con el que se inicia la cita, significa tanto "conceder u otorgar" como "eximir de una obligación". Entonces Unamuno ¿le pide al lector que le conceda el espacio para definir "novela" o que lo exima de esa obligación? O ¿le pide el espacio para definir "problema" o que lo exima de dar una definición? Porque a continuación define etimológicamente el término "problema". ¿No será entonces que, para Unamuno, hacer una novela es proyectar en el sentido de crear para resolver haciendo?, como bien continúa la cita. ¿No será entonces que la novela se asemeja a un problema?, ya que tanto en uno como en otro hay que presentar algo y, ambos suponen una creación, porque un problema, según él, supone más que una solución, una construcción, una creación. ¿Y qué supone la novela si no es una construcción, una creación? Unamuno, fiel al postulado romántico, hace de la palabra, creación. " [...] En el principio fue la Palabra, y por la Palabra se hizo todo [...]"26

Conocer el pensamiento de Unamuno nos puede dar ciertas claves para intentar dirimir la cuestión. Unamuno pide se le otorgue el privilegio como filólogo de definir el término, pero también pide que se lo exima de la obligación de dar una definición acabada. Porque quien busque algo acabado no merece ser su lector, ya que lo acabado, lo perfecto, es la muerte y la vida no puede morirse. ${ }^{27} \mathrm{Al}$ asemejar "novela" con "problema", como proyecto que se resuelve en la acción desde una creación y que se hace haciendo, posibilita abrir el campo semántico y pragmático de la novela. La novela como proyecto trasciende las fronteras del texto y en con-

\footnotetext{
25 Ibid.,p. 143.

26 Unmauno, M. de: Niebla, Buenos Aires, Espasa Calpe, 1993, p. 232.

27 Cfr. Unamuno, M. de: Cómo se hace una novela, Op. cit., p. 119.
} 
secuencia las establecidas por el autor, actualizándose en cada lectura haciendo al autor y al lector. Es el lugar abierto a la creación del lector, a una nueva interpretación. Por eso él hace otro Quijote, o mejor, desde el mismo Quijote, y desde los vacíos que el texto ha dejado al lector, ha descubierto honduras en ese texto que el mismo Cervantes no había descubierto.

La cuestión de la potencialidad semántica de la novela será recuperada en el cuarto apartado de este trabajo, cuando abordemos el tratamiento acerca de la función hermenéutica que cumple la novela en el pensamiento de Unamuno, a partir del análisis de Cómo se hace una novela. Pero antes de iniciar este análisis creemos que es insoslayable describir el recorrido que traza Unamuno en esta obra por un lado, y abordar posteriormente la cuestión de la recepción y del receptor de la obra literaria por otro, ya que a partir de la recepción de la obra se devela la función hermenéutica de la novela.

\subsubsection{Sobre la novela Cómo se hace una novela}

En este apartado nos ceñiremos a la descripción del trabajo realizado por Unamuno en Cómo se hace una novela, explicitando parte de la estructura de la obra y lo que podríamos considerar la trama, para profundizar acerca de la noción de "novela" unamuniana, y enriquecer posteriormente la relación entre distanciamiento y apropiación que Unamuno elabora en las páginas más teóricas de esta obra.

Cómo se hace una novela es una obra que, como tantas otras de Unamuno, es muy difícil clasificarla en un género literario, y esto es más bien voluntad expresa del autor. ${ }^{28}$ Ésta es una obra que incluye la novela, la autobiografía, el ensayo, y hasta el panfleto político. Unamuno la escribe en su estadía en París entre 1924 y 1925. La primera publicación de esta obra sale a la luz en 1926 en la revista el Mercure de France bajo el título Comment on fait un roman, precedido por un "Portrait d'Unamuno" hecho por Cassou a manera de prólogo. En 1927, Unamuno ya en Hendaya decide enviarla a publicar en español, ${ }^{29}$ pero como no contaba con el manuscrito original que había quedado en manos de Cassou en París, decidió retraducirse. Unamuno escribe o mejor, reescribe Cómo se hace una novela a partir de Comment on fait un roman, a la que le añade un prólogo y una serie de comentarios encorchetados.

Habitualmente, al enfrentarnos a una obra, lo primero a considerar es su título. Si en este caso el que lleva es Cómo se hace una novela, su lector no tendría, a prio$r i$, dificultad en entender que dicho libro le ofrecerá una serie de pautas, un conjun-

28 Cfr. Unamuno, M. de: Amor y pedagogía, Buenos Aires, Espasa Calpe, 1952, p. 81.

29 La primera edición en español se publica en Buenos Aires. Cfr. Unamuno, M. de: Amor y Pedagogía, Op. cit., p. 16. 
to de normas para realizar una novela. Pero Unamuno sabe -tan bien como lo expuso posteriormente Foucault- que podemos sospechar que el lenguaje no dice exactamente lo que dice, y que dice más de lo que dice; que el sentido manifiesto que se atrapa no es, sino un sentido menor, que encierra y transmite otro sentido más fuerte. 30 Por ello, quien crea que Cómo se hace una novela muestra las estrategias prácticas para la elaboración de una novela, ha caído en un malentendido. ${ }^{31}$ La lectura posterior quebrantará todas las expectativas que el título le ha despertado a un lector ingenuo -que no haya distinguido entre la dimensión semiótica y la dimensión semántica, entre la del significado (Bedeutung) y la del sentido (Sinn)- que crea que el significado del título queda plenificado en la letra del título. 32

Es importante recordar cuál debe ser la actitud de un lector para Unamuno, ya que rechaza y desprecia a aquellos lectores que tienen como interés prioritario seguir el desarrollo de la novela, cuando lo importante para él es la recepción íntima que la obra tiene para el lector. 33

Unamuno despliega en esta obra las estrategias fundamentales para una lectura seria, y por ello, va anticipando al lector continuamente el fracaso de sus expectativas. Esta es una lectura como meta-novela.

Estructuralmente, a partir de los estudios críticos, podemos afirmar que en esta obra nos encontramos con tres formas narrativas que se van intercalando y empujando unas a otras a lo largo de todo el texto. 34

\footnotetext{
30 Cfr. Foucault, M.: Nietzsche, Freud, Marx, Buenos Aires, El cielo por asalto, s/f , pp. 33-34

31 Tengamos en cuenta que para el fundador de la hermenéutica moderna, Schleiermacher, lo primero, antes de la comprensión es el malentendido, porque la comprensión no es espontánea, y precisamente la razón del malentendido es confundir Sinn con Bedeutung. Por tal motivo, para evitar el malentendido, o al menos, para morigerar sus efectos, Schleiermacher va a sostener que las precauciones hermenéuticas hay que tomarlas antes de encarar un texto, en virtud del carácter no espontáneo de la comprensión.

32 Ricoeur, P.: Del texto a la acción. Ensayos de Hermenéutica II, Buenos Aires, FCE, 2001, p. 142 Para deslindar el problema de la distinción entre "sentido" y "significado" Ricoeur atribuye al término "significación" "[...] una acepción muy amplia que abraca todos los aspectos y todos los niveles de la exteriorización intencional [...]” Sin embargo, unas líneas más adelante hará una especificación, ya que a partir de la noción de "obra" "[...] la idea de significado recibe una especificación nueva, referida a la escala de la obra individual. Por esta razón las obras tienen un problema de interpretación [...]" (Ricoeur, P.: Del texto a la acción ..., Op. cit., pp. 100-101). Asimismo indica que se atiene a "[...] una noción de sentido que se reduciría estrictamente a la combinación de los elementos de un texto, a la integración de segmentos de acción y de los actantes dentro del relato considerado como un todo cerrado en sí mismo." (Ricoeur, P.: Del texto a la acción..., Op. cit., p. 142)

33 Cfr. Unamuno, M. de: Cómo se hace una novela, Op. cit., pp. 110-120

34 Para un estudio más acabado de la estructura y de la metanovela de Cómo se hace una novela, recomendamos el capítulo correspondiente de la tesis doctoral citada de Luis A. Marcos. Y para un estudio de la novela en Unamuno, la obra de Carlos Longhurst, Teoría de la novela en Unamuno: de Niebla a Don Sandalio.
} 
Destacamos aquí tres partes de la obra: el núcleo de la novela; la traducción de Unamuno del "Portrait d'Unamuno"; y el diario.

En cuanto a lo que identificamos como el núcleo de la novela, tengamos en cuenta que éste ya no es el que era originariamente, ya que ha sido retraducido, primero del español al francés, y luego del francés al español, y en esta segunda traducción se agregan una serie de comentarios encorchetados ${ }^{35}$ que no estaban en el manuscrito original ni en la primera edición, la francesa. Esta parte puede subdividirse aún en más. En principio, se puede dividir en dos partes: la primera donde nos encontramos con el autor explicitando los motivos de lo que va a escribir, aunque no sólo los motivos personales, sino también los fines de la novela, los condicionamientos propios, sus propias lecturas, etc. La segunda parte se inicia con un párrafo indicando lo que vendrá. Y en el segundo párrafo comienza con la invención del personaje.

Pero estas dos subpartes del núcleo no se pueden leer linealmente, sobre todo la segunda, porque en ella, además de ir delineando la historia y las acciones del personaje U.Jugo de la Raza, irá intercalando comentarios, algunos originales y otros, los encorchetados, pertenecientes a la retraducción.

La primera parte del núcleo de la obra, si bien pareciera en principio ser una especie de prólogo a la edición original, en realidad comienza mostrando el sentir y las motivaciones de un escritor - o del escritor Unamuno- ante la hoja en blanco: "Héteme aqui ante estas blancas páginas -blancas como el negro porvenir: terrible blancura! -buscando retener el tiempo que pasa, fijar el huidero hoy [...]"36.

Esta terrible blancura de la página en blanco en la que se sume todo escritor, o mejor, todo novelista, no indica tanto la situación de un escritor ante el desafío de una página que aún está por escribirse, sino el desafío de un novelista que, ante lo fijado en esas páginas, buscar eternizarse.

Asimismo, la relevancia que la traducción tiene para Unamuno parece decisiva no sólo por lo explicitado por él en el texto, sino también porque lo que parecieran ser las dos partes principales de una obra son, o bien traducción o bien retraducción: hablamos aquí del prólogo que hace Cassou al original en francés y el núcleo de la obra. En la primera edición el prólogo es escrito originalmente en la lengua de la

\footnotetext{
35 La motivación del encorchetado es bien explícita en la obra como marca de escisión entre la retraducción y los comentarios. Retraducción que se le presenta como necesaria si ha de querer reponer esa obra, y no como una mera necesidad práctica para su publicación, sino como una necesidad vital que le impone repensar la obra y revivirla.

"Y ahora paso a retraducir mi relato de cómo se hace una novela. Y como no me es posible reponerlo sin repensarlo, es decir, sin revivirlo, he de verme empujado a comentarlo. $Y$ como quisiera respetar lo más que me sea hacedero al que fui, al de aquel invierno de 1924 a 1925, en París, cuando le añada un comentario lo pondré encorchetado, entre corchetes, así: [ ]." (Unamuno, M. de: Cómo se hace una novela, Op. cit., pp. 54-55)

36 Unamuno, M. de: Cómo se hace una novela, Op. cit., p. 59
} 
edición -francés-, pero el núcleo es una traducción -la realizada por Cassou del original de Unamuno. En la primera edición al español, tanto el prólogo de Cassou como el núcleo de la obra son traducciones. El prólogo una traducción y el núcleo una retraducción.

Es de destacar también la parte de la obra correspondiente al diario, que comienza a partir de una marca que el autor deja en el texto de la "Continuación", una continuación que parece no tener fin, ya que si bien la marca en el texto dice: "Terminado el viernes 17 de junio de 1927 [...]”. A párrafo seguido comienza el diario con fecha de martes 21 diciendo: “¿Terminado? ¿Qué pronto escribi eso! ¿Es que se puede terminar algo, aunque sólo sea una novela, de cómo se hace una novela? "37 Como ya sabemos, Unamuno no tiene gusto por lo acabado. La necesidad de retraducirse y la dificultad de respetarse a sí mismo en la retraducción, lo obliga a escribir el diario. No puede dar por terminado algo que, a partir de una nueva lectura, le posibilita un descubrimiento de los espacios que el texto ha dejado sin develar. Una nueva lectura lo lleva a una nueva interpretación, de la obra y de sí, del autor y del lector. El distanciamiento producido por la escritura, posibilita una nueva apropiación espacio temporal, un des-ocultamiento de aquello que en una lectura anterior permanecía entre sombras.

En el parágrafo anterior habíamos analizado la relación que Unamuno traza entre "problema" y "novela" con el objetivo de intentar definir qué entendía el bilbaíno por "novela". Es necesario ahora profundizar, si no en dicha relación, sí respecto de su noción de "novela". Qué se entiende por novela y qué entiende Unamuno por tal, es una cuestión que podríamos considerarla más filosófica que literaria.

Ofrecer una definición acabada de "novela" implica no considerar la variedad de significados e implicancias que ha tenido el término a lo largo de la historia, como asimismo en el pensamiento de Unamuno. Recuérdese que se afirmaba que podíamos hablar de "novela" en al menos tres sentidos: como género literario; como nivola; y como vida.

Uno de los componentes característicos de la novela tradicional, el de la construcción de la trama, parece no estar del todo claro en estas obras unamunianas, si definimos como lo hace Ricoeur en Tiempo y Narración, que en el plano más formal, la construcción de la trama la entendemos como una dinamismo integrador que extrae una historia, una y completa de un conjunto de incidentes. ${ }^{38}$ Pero el mismo Ricoeur va a sostener que en el campo de la novela moderna es donde más debe discutirse la pertinencia del concepto de construcción de la trama, a pesar de que la novela se presenta desde su nacimiento como un género proteiforme. Pese a los

\footnotetext{
37 Ibid., p. 144.

38 Ricoeur, P.: Tiempo y Narración II, México, Siglo XXI, 2008, p. 384.
} 
múltiples cambios sufridos por el género a lo largo de la historia, podemos coincidir con Ricoeur que, nada escapa al principio formal de configuración $\mathrm{y}$, por tanto, al concepto de construcción de la trama.

Como género literario, Cómo se hace una novela, contiene una novela en ciernes, un esquema de lo que sería una novela de U. Jugo de la Raza, pero sin desarrollarla. Y eso está entreverado con partes de un diario, comentarios, etc., mostrando una interconexión entre novela y vida, la vida como novela y la novela como vida, aunque una interconexión en la que ambos planos no se confunden, sino que se mantiene la distinción entre metáfora y realidad. No obstante y por ello, Cómo se hace una novela es una novela en otro sentido, más íntimo, más profundo. Unamuno noveliza su situación comparándose con Moisés, San Pablo, Dante, Mazzini y Víctor Hugo, y se da cuenta de que es el actor de su vida.

Lo que haría de las nivolas unamunianas una novela entonces, no es tanto la extensión, la narración en prosa, los incidentes y acciones, y sus personajes más o menos explícitos, sino más bien la construcción de una trama, aunque esa construcción no se haga legible en los personajes, sino en el autor y el lector. Es la construcción de la trama de una vida, de una vida íntima, entrañada, pero que se extraña al momento de escribirla, de fijarla y por ello necesita volver hacia sí. Exteriorización de su vida entrañada y extrañamiento a partir de la exteriorización dan cuenta de la agonía que, además de cómo hombre, vivía Unamuno como escritor.

Para Unamuno, el escribir contando cómo se hace una novela es hacerla. Y se pregunta si acaso no es más que una novela la vida de cada uno de nosotros. ${ }^{39}$ Así identifica aquí la trama de la novela con la trama de nuestra propia novela.

Considerando la distinción ricoeuriana de lo que podemos llamar la estructura o dimensión semiológica por un lado, y la dimensión semántica por el otro, ${ }^{40}$ puede que en la novela unamuniana, en la novela en su dimensión semiológica, la construcción de la trama no sea del todo clara y definida, sin embargo, sí lo es en su dimensión semántica, a pesar que aquí la trama se muestre de manera no idéntica a la multiplicidad de lectores. La construcción de la trama en la dimensión semiológica tiene en Unamuno una jerarquía menor en virtud de la carencia de vitalidad. Por eso afirma que como lo que escribe es una novela verdadera, no tiene intención de satisfacer los intereses del lector que quiere saber cómo acabarán los personajes de su novela. ${ }^{41}$ Y si algún lector se indignara por esta confesión -indica Unamuno-, entonces que no lo lea, porque no le será provechosa esa lectura. En cambio, cobra mayor interés en Unamuno la dimensión semántica del texto, que a su vez, permite la apertura a la dimensión pragmática.

39 Cfr. Unamuno, M. de: Cómo se hace una novela, Op. cit., p. 47.

40 Cfr. Ricoeur, P.: Del texto a la acción ..., Op. cit., p. 142.

${ }^{41}$ Cfr. Unamuno, M. de: Cómo se hace una novela, Op. cit., p. 110. 
La dimensión semántica de la novela, posibilita que el lector, mediante su imaginación actualice los vacíos que el texto deja abiertos en su dimensión semiológica, haciendo de esta manera al lector, un descubridor, un cocreador, un coautor. Como la trama no está del todo expuesta, cerrada, en su dimensión semiológica; cada lector irá cerrando la trama -si es que fuera posible hacerlo- en su dimensión semántica. Por eso dice Unamuno que "[...] cuando les cuente cómo se hace una novela, o sea como estoy haciendo la novela de mi vida, mi historia, les llevo a que se vayan haciendo su propia novela, la novela que es la vida de cada uno de ellos." 42

La trama de la novela unamuniana se juega entonces en la apertura que la dimensión semántica del texto posibilita para configurar la trama en su dimensión pragmática. Esto quedará más claro en adelante cuando indaguemos acerca de la función hermenéutica de la novela.

\section{La recepción del texto en el pensamiento de Unamuno}

En este apartado proponemos interrogarnos acerca de la posibilidad que Unamuno haya esbozado una teoría de la recepción estética a lo largo de su obra. Formulando el problema nos preguntamos, ¿es posible encontrar en el pensamiento y en la obra de Unamuno una prototeoría, o al menos un esbozo de una teoría de la recepción estética? Las respuestas a estas preguntas nos permitirán -creemosindagar de una manera más acabada la función hermenéutica que cumple la novela en el pensamiento de Unamuno.

Lo que hoy conocemos como la teoría de la recepción responde a una escuela de teoría literaria asociada con la Universidad de Constanza y con la revista Poetik und Hermeneutik.

Hans Jauss, a partir de mediados de la década del ' 60 se ha ocupado de la respuesta general a la literatura en términos de la estética de la recepción más que de la respuesta individual, sosteniendo que la obra literaria debería estudiarse en términos de impresión o impacto que produce en el público contemporáneo y que el valor literario se juzga de acuerdo con el grado en que se altera la percepción del texto con el paso del tiempo. Al respecto emplea la noción de "distancia estética" para indicar la diferencia entre la captación momentánea de una obra, al momento de la producción original y la actual. Manteniéndose la idea que el lector contribuye al proceso, hay aquí una especie de balance y cooperación entre el texto y lo que ofrece, y lo que el lector aporta, teniendo en cuenta que la pluralidad de lectores responden de manera diferente al texto.

42 Ibid., p. 54. 
De acuerdo a las diversas teorías de la recepción y de la respuesta del lector, todo texto tiene una potencia semántica que se actualiza, se completa, sólo con la lectura. Para Unamuno un texto, de por sí no dice nada, sino que es el lector quien lo hace hablar, como bien nos recuerda Longhurst al indicar que Unamuno, en ese sentido, se mantiene fiel a la tradición hermenéutica, tanto en su carácter de exégeta como de diseñador de textos. ${ }^{43}$ De esta manera, el lector no tiene un rol pasivo, sino que es un agente activo en la creación del significado.

Desde mediados de los "70 han surgido varias teorías sobre esta "colaboración". Wolfgang Iser en El acto de leer (1976) indica que todos los textos literarios tienen Leerstellen ("vacíos", "lagunas") que deben ser completados, concretizados por el lector para interpretar el texto.

El texto analizado en este trabajo fue publicado, como ya se ha señalado, originariamente en $1926^{44}$, cuarenta años antes del desarrollo de las teorías de la recepción, pero incluso en $1902^{45}$-sesenta años antes de la conformación de las teorías de la recepción- en su famosa nivola Amor y Pedagogía, el pensador vasco nos anticipa con la dedicatoria su ulterior trabajo acerca de la recepción estética plasmado posteriormente en Cómo se hace una novela. La dedicatoria de Amor y Pedagogía está dispuesta de la siguiente manera y reza así:

\author{
Al Lector, \\ dedica esta obra \\ El Autor
}

\begin{abstract}
43 Longhurst, C.: "La tradición hermenéutica en la narrativa unamuniana", en Chaguaceda Toledano, A. (ed.), Miguel de Unamuno, estudios sobre su obra, Vol.IV, Salamanca, Universidad de Salamanca, 2009 , p. 350 y 356. Sobre la misma cuestión también pueden verse otros artículos de mismo autor: "Unamuno y su problemática visión de la familia ibérica" (2008-2009); "Unamuno, the Reader, and the hermeneutical gap" (2008); "Unamuno, Schleiermacher, Humboldt: A Question of Language" (2011).

44 Cómo se hace una novela es publicada primero en francés bajo la traducción de Cassou, pero escrita el año anterior (1925) en español por Unamuno, y retraducida del francés al español por Unamuno en 1927 para su primera publicación española.

45 La referencias de Unamuno al lector provienen ya desde sus primeras obras: en En torno al casticismo, que reúne una serie de ensayos publicados por separado originariamente en 1895, son constantes las referencias al lector, y la metodología expresa ya en el primer ensayo, pone al lector en el papel de colaborador necesario. Esta presencia del lector en sus obras, incluso en sus novelas, puede que Unamuno la haya observado en el Quijote así como también en las obras de Kierkeggard, pero según Longhurst, en "La tradición hermenéutica en la narrativa unamuniana", es en la hermenéutica moderna donde hay que filiar la función del lector para Unamuno. Los ecos de la hermenéutica moderna le llegan a partir de la lecturas de los teólogos alemanes y franceses Schleiermacher y Sabatier, a quienes Unamuno cita frecuentemente, y a quien Orringer en Unamuno y los protestantes liberales establece un estudio sobre las lecturas del bilbaíno sobre ese protestantismo.
\end{abstract}


Analizar en esta dedicatoria el texto, su estructura y disposición, nos permite hacer varias observaciones. Por un lado, observamos que "lector" y "autor" Unamuno los escribe con letra capital, así tanto el lector como el autor denotan un nombre propio. Un autor particular, y un lector particular, cualquiera sea, pero el destinatario es uno, quien lo lea, así como el autor es uno. Dos individuos particulares vinculados a través del texto. Aquí no podemos confundir el uso de la letra capital para denotar un universal, porque precisamente para Unamuno, los universales son vacíos, son una nada, una ficción, y lo único realmente importante es lo individual. Unamuno mismo, en el prólogo a la segunda edición de Amor y Pedagogía, un prólogo añadido más de treinta años después de la primera aparición de esa obra, nos permite constatar el análisis anterior al afirmar que, cuando dice "Al Lector" está diciendo a cada uno de éstos y no a la masa. La transmisión del mensaje es a cada individuo, a cada vida individual, a su íntima individualidad, ${ }^{46}$ para que cada uno elabore su propia recepción.

Por otro lado, en cuanto a la disposición de la dedicatoria, nos encontramos con tres líneas que implican tres instancias: lector, obra y autor. Siguiendo el texto, Unamuno en esta dedicatoria parece dar mayor preeminencia a la figura del lector, dado que el término "lector" aparece primero en la dedicatoria, y es al Lector a quien le dedica la obra el autor, y no el Autor quien dedica la obra al lector. 47 Asimismo, la expresión que ocupa el lugar central: "dedica esta obra", nos permite pensar en que no hay obra sin autor y sin lector, la obra está atravesada por ambos. Pero como la preeminencia corresponde al lector, la obra es más un producto del lector que del autor mismo. En este caso, deberíamos ampliar el primer análisis y desdoblar el papel del autor ${ }^{48}$ para sostener que por un lado, el autor es uno, como un individuo particular, es quien escribe, quien determina los aspectos de la obra y a las vez deja los lugares de indeterminación, pero por otro, el autor no es uno, sino que el autor de la obra es tanto el autor como su lector, ya que es el lector quien, como sostiene Ricoeur, a través de la actividad imaginante, plenifica los vacíos dejados en el texto.

Este análisis parece condecirse con lo sostenido posteriormente por la teoría de la recepción en tanto que, como ya se ha dicho, todo texto se actualiza sólo con la lectura.

La metodología unamuniana de presentar en continua tensión sin resolución posible a los agonistas de sus nivolas contribuye a hacer del lector un sujeto activo, un colaborador eficaz, libre e incluso creativo.

46 Cfr. Unamuno, M. de: Amor y pedagogía, Op. cit., p. 18.

47 El uso de mayúsculas en esta oración pretende destacar estas diferencias.

48 Para un análisis más detallado de la noción de "autor" y su problematización, puede recurrirse a la obra De la gramatología de Derrida, a Los límites de la interpretación e Interpretación y Sobreinterpretación de Eco donde tematiza la noción de "intentio auctoris", como también a "¿Qué es un autor?" de Foucault. 
Unamuno, en el prólogo al prólogo de Cassou, afirma: "[...] Dice Cassou que mi obra no palidece. Gracias. Y es porque es la misma siempre. Y porque la hago de tal modo que pueda ser otra para el lector que la lea comiéndola [...].49

Claro! ¿Cómo podría palidecer una obra que siendo siempre la misma en virtud de lo escrito con la letra, en virtud de su dimensión semiótica, sea una y otra para cada lector en virtud de sus lecturas, de su dimensión semántica? Si como afirma Ricoeur, leer es percibir lo escrito pero suscitando lo imaginario, al mismo Unamuno le sucede lo propio con sus lecturas. Por ello, como afirma Marcos, para Unamuno, una misma expresión, en cada momento podrá tener significados distintos. ${ }^{50} \mathrm{Su}$ idea de Dios es distinta cada vez que la concibe. ${ }^{51}$ Aunque deberíamos decir quizá que su idea de Dios es distinta cada vez que la lee, ya que son los Leerstellen del texto los que le permiten concebirla una y otra vez de manera distinta a la vez que va completando su significado.

La potencialidad desplegada por la obra a partir de la lectura depende en gran medida, como afirma Jauss, del horizonte de expectativas en que se acoge un texto en tanto ilumina aspectos nuevos de esa obra. El papel desempeñado por la tradición 52 cobra aquí especial relevancia por cuanto la obra se concretiza bajo los aspectos determinantes de lo escrito por un lado, y bajo los lugares indeterminados, por los vacíos dejados en el texto que son actualizados desde nuestro horizonte de lectores, por otro. Por ello, a modo de advertencia preliminar, afirma Unamuno en la primera página del prólogo a la edición en español de Cómo se hace una novela:

[...] Sobre mí pesaba mi vida, que era y es mi muerte. Pesaban sobre mí no sólo mis sesenta años de vida individual física, sino más, mucho más que ellos; pesaban sobre mí siglos de un silenciosa tradición recogidos en el más recóndito rincón de mi alma; pesaban sobre mí inefables recuerdos inconscientes de ultra-cuna. ${ }^{53}$

Así recepciona nuestro lector sus lecturas, y como lector se hace autor. Un autor que "[...] su vida íntima, entrañada, novelesca, se continúa en la de sus lectores. Así como empezó antes [...]” ¿54 ¿Pero cómo empezó antes? ¿Cómo ha llegado a él la fuerza de la tradición? ¿Y cómo llega a cada uno de nosotros?:

\footnotetext{
49 Unamuno, M. de: Cómo se hace una novela, Op. cit, p. 41.

50 Marcos, L.A.: Op. cit., p. 27.

51 Cfr. Unamuno, M. de: Del sentimiento trágico de la vida, Op. cit., p. 138.

52 Las referencias al papel que cumple la tradición son constantes en En torno al casticismo (1902): "[...] la tradición es la sustancia de la Historia [...]”; "[...] La tradición vive en el fondo del presente [...]"; "[...] Tradición, de tradere, equivale a <<entrega $>>$ [...]; entre otras.

53 Unamuno, M. de: Cómo se hace una novela, Op. cit., p. 10.

54 Ibid., p. 148.
} 
[...] nuestra vida íntima, entrañada, novelesca, ¿empezó con cada uno de nosotros? [...] ¿hay hombres que no sean de libro? Hasta los que no saben ni leer ni escribir. Todo hombre, verdaderamente hombre, es hijo de una leyenda, escrita u oral.55

Esta potencialidad producida por la obra al actualizarse en sus múltiples lecturas, no sólo como decíamos antes con Jauss, puede iluminar aspectos nuevos de esa obra, sino que además, si un libro lo comemos - como recomienda Unamuno- que es mejor que leerlo, más que iluminar, alimenta 56 nuestra propia comprensión de nosotros mismos. Porque como dice nuestro autor, lo propio de una individualidad viva, siempre presente, siempre cambiante y siempre la misma, consiste en alimentarse de las demás individualidades y darse a ellas en alimento.57

La importancia del lector sobre el autor se revela en Unamuno no sólo a lo largo de toda esta obra que, como dicen varios comentaristas, debe considerarse como la obra que cifra las claves del pensamiento unamuniano, sino que también la podemos encontrar en las preguntas que el mismo Unamuno se hace a lo largo de este texto, cuando por ejemplo, respecto del retrato que Cassou hace de Unamuno, el pensador bilbaíno se pregunta ya en la retraducción y en los comentarios agregados, si no le ha hecho él, el retratado, el autor del retrato.58 Aquí Unamuno revela la importancia de la lectura para el lector, pero sobre todo para el autor, ya que es el lector quien, a través de la lectura, hace al autor, y al hacerlo, hace al autor del texto

55 Ibid., pp. 148-149.

56 A partir del uso que de los términos "alimentar" y "comerlo" hace Unamuno con sus metáforas alimenticias, quisiéramos intentar despejar una cuestión a la vez que ahondar en nuestro tema. Es frecuente en los ámbitos educativos escuchar que el término "alumno" es significado como "aquél que carece de luz" y que esa luz debe ser proporcionada por su maestro. Sin embargo, en estudios realizados acerca de la etimología del término "alumno", por ejemplo, en el Diccionario etimológico de términos utilizados frecuentemente en educación de Castello Dubrá, se indica que el término latino "alumnus" proviene originariamente de "alumens" y de "alere" (alimentar). De esta manera, en una pedagogía tradicional de tipo verticalista, el alumno se alimenta del docente, de sus conocimientos, haciéndose el alumno, maestro. Pero en las pedagogías que pretenden suprimir la relación vertical, al menos en lo formativo y cognitivo, ambos, docente y alumno, se alimentan uno del otro no sólo a través de los conocimientos que el docente puede transmitir (que los podríamos analogar a la letra del texto), sino a través de la transmisión de la tradición del docente y del horizonte de expectativas del alumno. Y así como Borges en "El escritor argentino y la tradición" nos decía que para bien o para mal. Todo lo que podamos escribir, enseñar o hacer con esa tradición -la europea recibida por los argentinos, no dejará de tener una huella argentina. Podremos decir tanto que todo lo que el docente enseñe no podrá dejar de tener una huella de su alumno, y todo lo que un autor escriba no podrá dejar de tener una huella de su lector. Porque tanto los alumnos como los lectores -receptores en general, y que tanto en Borges como en Unamuno tienen la nota de la productividad y no de la pasividad- están en mejores condiciones que los propios maestros y autores para abordar lo heredado puesto que, como Borges dice en dicho texto: pueden "[...] manejarlos sin supersticiones, con una irreverencia que puede tener, y tiene, consecuencias afortunadas".

57 Ibid., p. 49.

58 Cfr. Ibid., p. 54. 
leído trascender al resignificar su obra y su figura. Porque un texto, mientras hayas lectores, no se acaba nunca, y en ello radica su valor. 59

Al igual que en Schleiermacher, para Unamuno, un texto cualquiera está en relación con lo infinito dado que pertenece a un mundo, y ambos asignan una importancia a la singularidad en tanto cruce entre dos dimensiones: finitud-infinitud. Finito e infinito confluyen agónicamente de manera constante, así ninguna interpretación puede ser definitiva. La dialéctica finitud-infinitud, clave en el pensamiento de Schleiermacher60 y que deviene en el "círculo hermenéutico", la encontramos bajo términos muy semejantes, y resumidos también en la noción de "agonía" en Unamuno. ${ }^{61}$ La potencialidad de la lectura permite hacer de la finitud del texto, al actualizarse en las múltiples lecturas, la infinitud del significado. Esta relación agónica finitud-infinitud además constituye la base de la ontología unamuniana.

Unamuno en Cómo se hace una novela trae en su diario una anécdota sobre unos amigos de su juventud que hablan del concepto wagneriano de "melodía infinita". ¿Y qué es esta melodía infinita para él? Dice no saber bien cómo definirla, pero que debe ser como la vida y su novela, y como la historia, que nunca terminan. ${ }^{62}$ ¿Por qué dice esto? Porque los mejores novelistas no saben lo que han puesto en sus novelas, continuando sus vidas en la de sus lectores. La lectura de la obra permite así alimentar al lector y alimentarse de él. Alimentarse de ese finito para hacerse infinito.

Pero ¿cómo? ¿Cómo es posible que a partir de lo mismo, de lo repetido, en vez de identidad, encontremos pluralidad? Presas indica que Borges en "Pierre Menard, autor del Quijote", representa la no identidad de lo repetido, ya que, aun la repetición literal añade al viejo texto un nuevo sentido aportado por la distancia temporal y el diverso horizonte de expectativas. ${ }^{63}$ ¿Y qué es lo que hace Unamuno trece años antes 64 del Pierre Menard de Borges? Aun en la repetición literal añade al viejo texto un nuevo sentido, representando la no identidad de lo repetido, sin embargo no sólo hace eso, sino que también agrega más. El sentido (Sinn) se lo descubre en

59 Cfr. Unamuno, M. de: "El entierro del clasicismo", en Obras completas, Op. cit., Vol.VII, p. 1296.

60 Cfr. Schleiermacher, F.: Ermeneutica, Milano, Rusconi, 1996, p. 205 y pp. 305-307.

61 De esta cuestión da cuenta también el artículo de Ingwersen, S.: "Unamuno and Schleiermacher: the "agonic style" and Protestant hermeneutics", Anglican Theological Review, Vol.67, No3, 1985, pp. 260-272, donde además de explorar las afinidades teológicas y filosóficas entre Schleiermacher y Unamuno, compara, a través del análisis textual, el pensamiento de ambos para indicar la probabilidad de una influencia directa del filósofo alemán sobre Unamuno, ejercida por "adivinación", a la hermenéutica de estilo agónico de los Ensayos unamunianos.

62 Unamuno, M. de: Cómo se hace una novela, Op. cit., 144.

63 Cfr. Presas, M.: Del ser a la palabra. Ensayos sobre estética, fenomenología y hermenéutica, Buenos Aires, Biblos, 2009, p. 125.

${ }^{64} \mathrm{La}$ obra Cómo se hace una novela tiene su primera publicación en 1926, trece años antes que el

"Pierre Menard..." de Borges. 
el lenguaje poético y simbólico, que nunca ofrece univocidad, sino que más bien está en continuo movimiento de envío hacia otros significados ocultos pero latentes. La necesidad unamuniana de retraducirse al retraducir su obra desde la traducción de Cassou, le hace decir en las páginas iniciales del prólogo que al hacerlo, al retraducirse, le será imposible mantenerse fiel a aquel momento que pasó, ${ }^{65}$ ya que no le es posible reponerlo sin repensarlo, sin revivirlo. 66

Jauss reconoce entre otros a Paul Valéry como uno de los precursores de este nuevo paradigma histórico-hermenéutico de la teoría de la recepción, quien eleva al lector a la categoría de cocreador de una obra. De esta manera, corresponde al lector el papel de completar un sentido que no está dispuesto, sino más bien, propuesto a partir de los Leerstellen. Insausti Ugarriza sostiene que el lema de Unamuno, en Vida de Don Quijote y Sancho es, mejor que crear es re-crear a Don Quijote, y cuando Unamuno habla de Quijotismo o de una filosofía quijotesca, por ello entiende una interpretación productiva, no meramente reproductiva de las figuras de Don Quijote y Sancho. No se trata, dice el comentarista, de una interpretación histórica o crítico-literaria, sino de una interpretación nueva, a veces dirigida incluso contra el mismo Cervantes. ${ }^{67}$ Unamuno lee al Quijote desde la indeterminación determinada por el texto, desde sus vacíos, y así por ejemplo ve y construye a la figura de Sancho -que por eso, a diferencia del de Cervantes, lo incluye en el título de su obra-, como la contracara necesaria del Quijote. El Unamuno lector, cuando construye a su Quijote y a su Sancho, los crea en una tensión agónica que no puede desaparecer, ya que la muerte de uno equivaldría a la muerte del otro, complementándose necesariamente en la diferencia, y no en la identidad.

Entre las variadas expresiones que encierra la concepción de Unamuno sobre el receptor en Cómo se hace una novela, podemos encontrar que una obra queda abierta a una pluralidad de lectores, una obra nunca puede ser cerrada, finita, terminada, 68 porque lo acabado es lo muerto.

La multiplicidad de lecturas posibilita que cada lector haga su propia novela creando o recreando sus personajes y su sentido. Es la novela, en tanto leída, el lugar abierto a la creación del lector. En este caso, todo texto novelesco está abierto a una nueva interpretación, y toda nueva interpretación pasará a formar parte de la historia de esa novela, y por tanto, también de la novela, como señala el mismo Unamuno en un artículo titulado "Historia de Niebla" que a la vez forma parte de ella misma. ${ }^{69}$ La relevancia que adquiere el lector a lo largo de toda la obra unamu-

\footnotetext{
65 Unamuno, M. de: Cómo se hace una novela, Op. cit., p. 15.

66 Ibid., p. 54

67 Insausti Ugarriza, X.: "Unas pinceladas sobre la obra y la figura de Unamuno", Riev, 41, 1, 1996, p. 45.

68 Cfr. Unamuno, M. de: Cómo se hace una novela, Op. cit., p. 144.

69 Marcos, L.A.: Op. cit., pp. 436-440.
} 
niana revela la influencia del más puro romanticismo, a la vez que da cuenta de la afinidad con la hermenéutica filosófica en tanto que el lector, como receptor de la obra, está llamado a la interpretación y comprensión de la historia, de la vida, de los pueblos, y de la historia de la vida de los pueblos, a través del discurso fijado por la escritura.

\section{De la recepción a la comprensión}

A Unamuno le preocupa ser comprendido por sus lectores,${ }^{70}$ ¿pero qué es ser comprendido para Unamuno? ¿Qué entiende Unamuno por comprender? El bilbaíno para dar cuenta de ello nos remite a la definición que Abbagnano brinda en Le sorgenti irrazionali del pensiero (1923): ${ }^{71}$ "Comprender no quiere decir penetrar en la intimidad del pensamiento ajeno, sino tan sólo traducir en el propio pensamiento, en la propia verdad, la soterraña experiencia en que se funde la vida propia y la ajena. "'72 En primer lugar vemos aquí que Abbagnano parece poner en tela de juicio aquella concepción schleiermarcheriana de la "comprensión" que nos indica que la comprensión se produce a partir de establecer una empatía con el autor, donde el intérprete al invadir al otro, se convierte en el otro para comprenderlo y donde el sujeto queda absorbido por la alteridad, perdiéndose. La crítica de Abbagnano a la empatía parece devenir en una concepción de la comprensión como traducción que requeriría de un esfuerzo menor de parte del receptor/traductor/intérprete que la comprensión por empatía. Para el filósofo italiano, "comprender" no es tanto lograr una empatía con el otro, sino más bien traducir la experiencia en que se funde la vida propia y la ajena en nuestro propio pensamiento. Pero ¿qué significa traducir en mi pensamiento la experiencia en que se funde la vida propia y la ajena? ¿No comportaría esta traducción una apropiación del otro por mí y en mí? Intentemos aquí responder a la segunda cuestión, la primera vamos a responderla unas líneas más adelante a partir de las palabras del propio Unamuno.

El término "comprender" deriva de "prender", proveniente del latín "prehen$d o$ ", "atrapar". Así, comprender es un "traer", "traer a casa", a la casa propia, hacer algo parte de mí. La comprensión comporta así una apropiación.

Anteriormente vimos que uno de los modos posibles de apropiación es el que precisamente sugiere la hermenéutica romántica de Schleiermacher para quien, para

\footnotetext{
70 Cfr. Unamuno, M. de: Cómo se hace una novela, Op. cit., p. 141

71 En ésta, su primera obra, Abbagnano, reconstruye la teoría filosófica desde Platón hasta el presente sobre el problema de la conciencia, el de la distinción pensamiento-realidad y sobre todo el de la posibilidad de fundar la verdad.
}

72 Citado por Unamuno en Cómo se hace una novela, Op. cit., p. 141 
comprender un texto, es necesario establecer una corriente empática con su autor, trasladándose a la mente del autor, "ir a la casa" del autor, y al hacerlo participa de una recreación activa de su obra. Se convierte en un coautor, perdiéndose, olvidándose de sí al identificarse por completo con el autor. Pero este "ir a la casa" tiene un fin, que es "traerlo", prenderlo, asirlo, hacerlo suyo, para comprenderlo.

Retomando la cuestión, ¿qué significa entonces traducir en mi pensamiento la experiencia en que se funde la vida propia y la ajena? Todo acto de comprensión parece descansar en una identidad entre el "tú" y el "yo" que hace posible la comprensión pese a las diferencias. En un movimiento triple, comprendo, recién allí cuando, el traductor invade (la esfera del otro), extrae (del otro) y trae a casa (al otro)..$^{73}$ Para traducir tengo que ir hacia lo que tengo que traducir, es un movimiento invasivo, para luego traerlo, hacerlo mío.

Nos preguntábamos si ¿no comportaría esta traducción una apropiación del otro por mí y en mí? A continuación de la definición que cita Unamuno de Abbganano, el pensador vasco se pregunta:

Pero [lo que define Abbagnano como "comprender"], ¿no es eso acaso penetrar en la entraña del pensamiento de otro? Si yo traduzco en mi propio pensamiento la soterraña experiencia en que se funde mi vida y tu vida, lector, o si tú traduces en el propio tuyo, si nos llegamos a comprender mutuamente, a prendernos conjuntamente $[\ldots] .74$

Unamuno viene a cuestionar la distinción que pretende establecer Abbagnano entre "penetrar" y "traducir" para luego hacer propia la definición, indicando que la noción de "comprensión" del italiano, implica también una empatía análoga a la que quiere criticar.

Unamuno, en su obra ha intentado traducir a pensamiento propio la experiencia suya y ajena. Esto es también lo que han hecho los personajes de las novelas unamunianas, desarrollar una traducción propia: Abel Sánchez, es visto, traducido, por Joaquín Monegro, San Manuel es visto y traducido por Ángela, Teresa por Rafael, Don Sandalio por su amigo, etc. Estos personajes son traductores de la experiencia ajena y propia al pensamiento y experiencia de cada uno de ellos, y son también, por tanto, autores. 75

Tal cual hemos visto, al momento de la comprensión le precede, como una parte, el de la apropiación. Tenemos entonces que el texto, es recepcionado por el lector que, al intentar apropiarse para traducirlo y para comprenderlo, viaja hacia el autor (o hacia el texto) a través del texto (o a través del autor), y de esta manera lo

\footnotetext{
73 Rossi, M.J.: "La hermenéutica y la investigación filosófica", http://hum.unne.edu.ar/revistas/postgrado/revista2/4_rossi.pdf, Universidad Nacional del Nordeste, s/f, p. 3.

74 Unamuno, M. de: Cómo se hace una novela, Op. cit., p. 141.

75 Marcos, L.A.: Op. cit., pp. 465-466.
} 
recrea. Pero entre texto y lector hay una distancia hermenéutica dada por la dimensión semiológica del texto.

La constatación de la distancia entre texto y lector pone al hermeneuta en una disyuntiva: o sacrifica su sí mismo al texto, o somete el texto a sí mismo. La primera actitud comporta una pérdida del sujeto en favor de la alteridad, la segunda en cambio reivindica los derechos de una subjetividad autoafirmativa. ${ }^{76}$

Abbagnano en la definición citada de "comprensión" parece oponerse a esta primera alternativa de la distinción, ya que al penetrar en la intimidad del pensamiento del otro, nos perdemos en la alteridad. Pero el cambio de "penetrar" por "traducir", como bien dice Unamuno, no modifica demasiado, ya que para traducir tenemos que invadir, penetrar en el otro perdiéndonos.

Sin embargo, Unamuno agrega algo más al preguntarse si este traducir:

[...] ¿no es que he penetrado yo en la intimidad de tu pensamiento a la vez que penetrabas tú en la intimidad del tuyo y que no es ni mío ni tuyo común de los dos? ¿No es acaso que mi hombre de dentro, mi intra-hombre, se toca y hasta se une con tu hombre de dentro, con tu intra-hombre de modo que yo viva en ti y tú en mi?77

Esta pregunta permite mostrar la posibilidad de una redefinición unamuniana de la noción de "comprensión", donde lo novedoso pasa por una pérdida y una ganancia mutua. Si para traducir, tenemos que penetrar en la intimidad del pensamiento del otro, allí hay una pérdida para el traductor en la alteridad del traducido. Sin embargo, a la vez que invadimos la esfera del autor, del otro, perdiéndonos, perdiendo el sujeto en favor de la alteridad, hay también allí una pérdida para el otro, ya que a la vez que hemos penetrado, invadido la intimidad del pensamiento del otro, penetraba el otro en la intimidad de su propio pensamiento y en el mío; pensamiento que en definitiva pertenece a la universalidad de lectores, de intérpretes una vez que la palabra y el pensamiento se hacen texto. En un mismo acto se producen los dos polos de la disyuntiva que devienen ahora conjuntiva. El lector no es quien debe ponerse en lugar del autor, sino que, el lector al ponerse en lugar del autor, el autor también se pone en su lugar y en el lector. Ello permite que como se pregunta Unamuno hacia el final de la cita, el lector viva en el autor a la vez que el autor viva en el lector, y quizá deberíamos añadir, perviva en el lector. El lector es quien permite que el autor trascienda, se encuentre, en la multiplicidad de lecturas.

[...] Porque el que lee una novela, puede vivirla, revivirla -y quien dice una novela dice una historia- y el que lee un poema, una criatura- poema es criatura y poesía creaciónpuede re-crearlo. Entre ellos el autor mismo. ${ }^{78}$

\footnotetext{
76 Rossi, M.J.: Op. cit., p. 4

77 Unamuno, M. de: Cómo se hace una novela, Op. cit., p. 141

78 Ibid., pp. 14-15
} 
Unamuno parece haberse encontrado en la lectura y traducción que hizo Cassou de Cómo se hace una novela, y por eso se retradujo comentándose, recreándose. Unamuno, perdiéndose en la lectura de Comment on fait un roman se encuentra con un nuevo Unamuno que necesita, al revivirse, retraducirse. Para traducir hay que invadir primero, hay que penetrar, hay que ir para traer en un viaje donde, en principio nos perdemos, para luego encontrarnos.

François Meyer en una de las obras críticas más conocidas sobre el pensamiento ontológico de Unamuno, sostiene que ontológicamente, se enfrentan en tensión dos movimientos, el extenderse hacia lo exterior y atraerlo hacia él, 79 ya que Unamuno quiere ser él, y sin dejar de serlo, ser además los otros. Ensanchar sus linderos al infinito, pero sin romperlos. ${ }^{80}$ De esta manera, no es en nosotros mismos, sino fuera de nosotros donde nos encontraremos sostiene Meyer, ${ }^{81}$ quien afirma que esta idea se precisa en la distinción que Unamuno hace frecuentemente, entre individualidad y personalidad. ${ }^{82}$ En este sentido, hay que perderse para encontrarse, hay que salirse, irse, penetrar en el otro para, al traerlo, encontrarnos.

La función hermenéutica es doble, suprimir la distancia, invadiendo, yendo a la "casa del otro" por una parte, y hacer propio, prenderlo, "traer a casa", lo que se interpreta, por otra.

Los filósofos de la sospecha nos han revelado que ya no es posible identificarse con lo que el autor quiso decir y no dijo, y que no es posible pensar en una subjetividad autoafirmativa. Dado que con Nietzsche, Marx y Freud no parece posible una filosofía construida sobre el fundamento inconmovible de la certeza del cógito cartesiano, se cree más bien que el hombre debe ser concebido como un ser histórico, que se va haciendo y cuya identidad se va encontrando en la rememoración de su propio pasado. ${ }^{83}$ No es como en el caso cartesiano, una identidad abstracta, sino más bien una identidad narrativa como bien la ha denominado MacIntyre. En este sentido, el hombre no sólo tiene una historia, sino que es historia, es proyecto, aun sabiéndose situado, ya que es capaz de recrear y recrearse a partir de la imaginación, de la misma manera que lo hace el novelista.

Unamuno es bien claro en este punto. Para conocerse no hay intuición directa de sí mismo que valga, sino que del conocimiento de nuestras obras es como logramos el conocimiento de nosotros mismos. El espejo del hombre son sus obras, y la

\footnotetext{
79 Cfr. Meyer, F.: La ontología de Miguel de Unamuno, Madrid, Gredos, 1962, p. 63

80 Cfr. Unamuno, M. de: Del sentimiento trágico de la vida, Op. cit., p. 103

81 Meyer, F.: Op. cit., p. 63

82 Unamuno en Del Sentimiento trágico de la vida, dedica estas palabras a la distinción entre "personalidad" e "individualidad": “(...) La individualidad es, (...), el continente, y la personalidad, el contenido; o podría también decir en un cierto sentido que mi personalidad es mi comprensión, lo que comprendo y encierro en mí (...), y mi individualidad es mi extensión; lo uno, lo infinito mío, y lo otro, mi finito (...). (Unamuno, M. de: Del sentimiento trágico de la vida, Op. cit., p. 190)

83 En el mismo sentido puede verse en Unamuno su obra En torno al casticismo.
} 
literatura española, por cuanto el arte parece ir más asido al ser, muestra la más pura cepa castellana. ${ }^{84} \mathrm{Y}$ esto lo sabe bien desde que escribió su tesis doctoral:85 para comprender no hay otra solución que acudir a la literatura. El hombre y los pueblos se conocen a través de sus obras. Es así como justificamos una interpretación del pensamiento de Unamuno como hermenéutica filosófica, una filosofía, por lo demás, enraizada en su época.

La relevancia que la fijación a través de la escritura tiene en Unamuno pone de manifiesto que, sin libro no habría conciencia. ${ }^{86}$ Siendo el libro lo que une o separa "[...] la parte exterior, las extrañas, y la parte interior, las entrañas." Y nos comunica "[...] el yo exterior, el social, con el yo interior, el individual." 87 En tanto hombres bíblicos, nos sabemos situados por nuestro pasado, somos, como diría Unamuno, un ser expósito condenado a nuestra intrahistoria. ${ }^{88}$

Esto nos lleva a indagar la cuestión de la distancia hermenéutica, y a profundizar la de la apropiación.

\section{La función hermenéutica del texto}

En este apartado, siguiendo fundamentalmente a Ricoeur proponemos dar cuenta de la función hermenéutica de la obra de ficción en torno al pensamiento unamuniano.

La reivindicación del carácter referencial del uso poético del lenguaje alcanza al relato de ficción. ${ }^{89}$ Este uso del lenguaje si bien obstruye la referencia directa, inmediata, permite que surja otra relación. El movimiento que realiza Ricoeur en Del texto a la acción supone que al aclarar la función de la narración, se aclara también la referencia de la obra misma, se aclara cómo ella es capaz de influir en la actitud que el hombre adopta ante el mundo y la vida. ${ }^{90}$ Esto se pone de manifiesto

\footnotetext{
${ }^{84}$ Cfr. Unamuno, M. de: "La tradición eterna" y "La casta histórica Castilla", en En torno al casticismo, Madrid, Alianza, 1986

85 La tesis doctoral de Unamuno, defendida en 1884, llevaba por título Crítica del problema sobre el origen y prehistoria de la raza vasca.

${ }^{86}$ Cfr. Unamuno, M. de: Cómo se hace una novela, Op. cit.,p. 67

87 Unamuno, M. de: "El hombre del libro" en Obras Completas, Op. cit., VII, pp. 1456-57

88 El término "Intrahistoria" podría definirse como la historia interna de un pueblo. El sedimento que dejan los aportes de los hombres que componen ese pueblo. Sin embargo, no podemos delimitar con precisión la noción del término "pueblo" ya que su vaguedad podría permitir identificarlo como "el pueblo de Occidente", "el pueblo cristiano", "el pueblo salamanquino", etc.

${ }^{89}$ La función del relato de ficción la podemos definir con Presas como la ordenación sintética de múltiples sucesos en la unidad de una trama en la que el hombre se cuenta y da cuenta de la perplejidad de su propio experimentarse como ser temporal e histórico. (Presas, M.: Op. cit., p. 76)

90 Ricoeur, P.: Del texto a la acción..., Op. cit, p. 76
} 
cuando analizamos las relaciones que establece Ricoeur entre "distanciamiento" y "apropiación".

Dejaremos de lado en este análisis la función de la metáfora aislada para centrarnos en la función de la narrativa.

La innovación semántica que se produce en la obra narrativa se da por medio de la invención de una fábula, de un mythos, de lo que Ricoeur denomina mise en intrigue. ${ }^{91}$ Ya habíamos anticipado cómo la obra unamuniana podía inscribirse, aunque no en el sentido tradicional quizá, dentro de la categoría de mythos aristotélico o construcción de la trama. Teniendo en cuenta esto $\mathrm{y}$, sumado a lo que podríamos denominar una prototeoría de la recepción en la obra unamuniana, y a su análisis de la noción de "comprensión", pretendemos dar cuenta de la función hermenéutica que cumple la obra de ficción para nuestro autor, 92 función que deviene, o mejor, se traduce en una función pragmática que se constituye en la intención vital del autor. 93

\subsection{Distanciamiento y apropiación en el pensamiento de Unamuno}

En Cómo se hace una novela, a propósito de la necesidad de retraducirse, nuestro autor nos dice que:

[...] En cuanto un pensamiento nuestro queda fijado por la escritura, expresado, cristalizado, queda ya muerto, y no es más nuestro que será un día bajo tierra nuestro esqueleto. [...] y la literatura no es más que muerte. Muerte de que otros pueden tomar vida. $[\ldots] \mathrm{Y}_{i}$ es que siempre un autor al volver a leer una pasada obra suya, vuelve a encontrar la eternidad de aquel momento pasado que hace el presente eterno? [...] Y he aquí porque es trágica tortura la de querer rehacer lo ya hecho, que es des-hecho. En lo que entra a retraducirse a sí mismo. Y sin embargo...

\footnotetext{
${ }^{91}$ La mise en intrigue consiste en la selección y arreglo de los acontecimientos y de las acciones contadas, que hacen de la fábula una historia completa y entera que tenga un comienzo, un medio y un fin.

92 Ya la teoría hermenéutica de Mario Valdés toma como referencia la obra de Miguel de Unamuno, quien consideraba el acto de lectura como un intercambio entre el yo y el conjunto de los restantes lectores. La literatura se convierte así en un diálogo abierto con el otro, un proceso en el que el lector construye su propia personalidad tomando como referencia la multiciplicidad de perspectivas que ofrece la hermenéutica de la obra literaria. Asimismo Valdés, en una entrevista que le realizaron en 2003 para el Boletín Gallego de Literatura, sostiene que la hermenéutica fenomenológica llevada a cabo por Ricoeur tiene como iniciador a Unamuno.

93 Respecto de la función pragmática de la novela como "intención originaria del autor", cabe advertir que su desarrollo excede los límites de este trabajo, pero es posible indicar brevemente que, la intención de Unamuno es tratar de responder a la pregunta "para qué". Este "para qué" se constituiría como el fin de su ontología y de su epistemología.
} 
Sí, necesito para vivir, para revivir, para asirme de ese pasado, que es toda mi realidad venidera, ${ }^{94}$ necesito retraducirme. Y voy a retraducirme. Pero [...] me va a ser imposible mantenerme fiel a aquel momento que pasó. El texto, pues, que dé aquí, disentirá en algo del que traducido al francés apareció en el número de 15 de mayo de 1926 del Mercure de France. Ni deben interesar a nadie las discrepancias. Como no sea a algún erudito futuro. 95

La extensa cita tiene su razón de ser. Aquí encontramos concentrada, gran parte de las ideas que Unamuno desarrolla en torno a la relación autor-lector, a la recepción del texto, y a la función hermenéutica de la obra.

La fijación mediante la escritura es la que posibilita, contrariamente a lo que pareciera, la apertura del texto, y por ende, como ya veremos, la apertura del mundo. Es mediante el texto, y a partir de la lectura de las lagunas dejadas en él, como se puede descubrir la historia y la vida de un hombre y de un pueblo.

Unamuno para retraducirse necesita repensarse y revivirse, porque quien lee una novela, incluido el propio autor, la vive, la revive, y puede re-crearla. Por eso se pregunta nuestro autor: ¿es que siempre un autor al volver a leer una pasada obra suya, vuelve a encontrar la eternidad de aquel momento pasado que hace el presente eterno?

En Ricoeur, la fijación por la escritura es precisamente lo que posibilita revitalizar y reformular la tensión suscitada por Dilthey entre "explicación" y "comprensión”. Esta fijación por la escritura es lo que le permite acudir a la noción de texto, y lo que fija toda escritura en un texto es un discurso.

Vamos a plantear aquí, al menos brevemente, una relación que le es útil a Ricoeur para dar cuenta de las propiedades del texto. Antes de llegar a este punto, Ricoeur se pregunta si la fijación mediante la escritura que es un texto, significa que el discurso primero debió ser pronunciado física o mentalmente, o que lo que fija la escritura es un discurso que se habría podido decir, pero que precisamente se escribe porque no se lo dice. 96 Con esta pregunta establece la posibilidad de que un texto se dé a partir de dos situaciones: como la transcripción del habla a la escritura, o como la escritura en lugar del habla. ${ }^{97}$ Esta última forma es la que hace del texto, el lugar donde se produce un acontecimiento, texto que, por tener esta propiedad,

\footnotetext{
94 La relación histórico-temporal entre pasado y futuro son una constante en los estudios unamunianos realizados en En torno al casticismo.

95 Unamuno, M. de: Cómo se hace una novela, Op. cit., pp. 14-15.

96 Ricouer, P.: Del texto a la acción ..., Op. cit., pp. 127-128.

97 En el artículo "Cosas de Libros" de 1918, Unamuno piensa que el comienzo del Evangelio de San Juan podría sustituirse por otro que dijera "en el principio fue la Escritura". Porque de nada habría servido esa palabra si no hubiera quedado escrita. Algo así como le sucede al mismo San Juan, que aún para afirmar la Palabra, debió escribirla. Para Unamuno el conocimiento pasa por la expresión escrita y no por la palabra hablada.
} 
hace de él, a partir de la lectura, una obra que se actualiza en y por la lectura, dando al texto el carácter de abierto. Por eso dice: "[...] la escritura convierte al texto en algo autónomo con respecto a la intención del autor. Lo que el texto significa ya no coincide con lo que el autor quiso decir. [...]"] Por eso "¿Qué me importa que no leas, lector, lo que yo quise poner en ella [...]? [...] lo que nos importa no es lo que quiso decir [el autor] sino lo que dijo, [...]" "99 En este sentido, sostiene Ricoeur que "[...] esta primera modalidad de la autonomía nos anima a reconocerle al Verfremdung una significación positiva [...]”100

Este distanciamiento producido por la fijación mediante la escritura es lo que le hace decir a Unamuno que un pensamiento suyo, escrito, ya no es suyo, y que en ese sentido, lo positivo de esa pérdida está en que puede ser recuperado luego por otros, revivido, recreado, incluso por el autor mismo, como en el caso de Cómo se hace una novela. Por esto mismo le gusta decir a Ricoeur que leer un libro es considerar a su autor como ya muerto y al libro como póstumo, ${ }^{101}$ porque de esa manera, evitamos entrar en un diálogo directo con el autor quedando sólo su obra para leer.

De esta manera, "[...] la apropiación está dialécticamente ligada al distanciamiento característico de la escritura. [...] es su contrapartida. Gracias al distanciamiento por la escritura, la apropiación ya no tiene ninguno de los rasgos de la afinidad afectiva con la intención de un autor."102 La apropiación es todo lo contrario de la contemporaneidad y de la congenialidad; y así es comprensión por la distancia y $a$ distancia. De esta manera, el distanciamiento es condición de la comprensión.

Por esto mismo se pregunta Unamuno "[...] ¿y para qué tiene el lector que ponerse de acuerdo con lo que el escritor le dice? Por mi parte cuando me pongo a leer a otro no es para ponerme de acuerdo con él. [...]"103 Este distanciamiento por la escritura es lo que le permite al bilbaíno aquello que le permitía a Schleiermacher y a Dilthey la empatía con el autor. En todo caso, poder conocer al autor mejor que el autor mismo se da a partir de la función del distanciamiento que produce la escritura, y no mediante la apropiación de la vida psíquica del otro.

Unamuno, consciente de ello, se dirige a sus lectores, como en numerosas ocasiones, diciendo:

Por ahora, mis jóvenes, aquí os lo dejo escrito,

\footnotetext{
98 Ricouer, P. : Del texto a la acción..., Op. cit., p. 104.

99 Unamuno, M. de: Cómo se hace una novela, Op. cit, p. 41.

100 Ricoeur, P.: Del texto a la acción ..., Op. cit., p. 104.

101 Ibid., p. 129.

102 Ibid., p. 109.

103 Unamuno, M. de: Cómo se hace una novela, Op. cit., p. 49.
} 


\author{
y si un día os negare \\ argüid contra mí conmigo mismo, \\ pues os declaro \\ -y creo saber bien lo que me digo- \\ que cuando llegue a viejo, \\ de éste que ahora me soy y me respiro, \\ sabrán, cierto, los jóvenes de entonces \\ más que yo si a éste yo me sobrevivo. 104
}

La supervivencia del autor a través del texto, y del distanciamiento producido por la escritura no sólo posibilita la comprensión del texto, sino también la autocomprensión, ya que ésta pasa por el rodeo de la comprensión de los signos de la cultura. 105

En Unamuno, a partir de Cómo se hace una novela, la posibilidad de la autocomprensión se manifiesta a través de la necesidad de retraducirse, porque esta retraducción, no es una transcripción, y por eso, repasando, antes de retraducirse, el retrato que hiciera Cassou de él, se ve no sin asombro en él como en un espejo, pero en un espejo tal que vemos más el espejo mismo que lo en él espejado. 106

De esta manera, el texto es, como sostiene Ricoeur, la mediación por la cual nos comprendemos a nosotros mismos, es un médium en el cual nos podemos comprender. Pero como lo que se ha de interpretar en un texto, es el proyecto de un mundo, el que yo podría habitar, cabe entonces indagar brevemente sobre la función cognoscitiva de la obra de ficción.

\subsection{Del conocimiento a través de las obras a la dimensión pragmática de la obra}

En la ficción, a diferencia de lo que ocurre en la vida cotidiana, se pone al descubierto un orden oculto de la experiencia del hombre que no advertimos su sentido y que podemos verlo más claramente a través de la narración. En el tiempo de la narración se reconfigura el tiempo de nuestra vida. Hay un des-cubrir que podríamos analogar al descubrir, al develar, que lleva a cabo el análisis crítico. Sometemos a crítica la vida a través de la narración mediante el des-ocultamiento de lo que en nuestra vida nos pasa inadvertido. ¿Pero acaso no será posible pensar que lo descubierto es lo creado? 107 Porque "A un hombre de verdad se le descubre, se le crea,

\footnotetext{
104 Unamuno, M. de: "Poesías", en Obras Completas, Op. cit., Vol.VI, p. 172

105 Ricoeur, P.: Del texto a la acción ..., Op. cit, p. 141

106 Unamuno, M. de: Cómo se hace una novela, Op. cit, p. 36

107 "Descubrir", para Unamuno es sinónimo de creación, es un des-ocultamiento a partir de los vacíos que deja el texto. (Cfr. Unamuno, M. de: Tres novelas ejemplares y un prólogo, Op. cit., pp. 19-20). Recordemos que Gadamer, en Verdad y Método, señala que "descubrir" supone lanzarse a una inter-
} 
en un momento, en una frase, en un grito. [...] Y luego, que le hayáis descubierto, creado, lo conocéis mejor que él se conoce a sí mismo acaso. ”108

En esta capacidad de la ficción de refigurar esa experiencia temporal es donde reside la función referencial de la intriga sostiene Ricoeur. ${ }^{109}$ Como en la literatura nos encontramos ante un texto sin interlocutor, no tenemos allí presente ni autores ni lectores con sus mundos, el texto se me presenta por la distancia que muestra, como un absoluto irreferente. En consecuencia, tenemos ahora que habérnosla con el texto mismo, tenemos que interpretar lo que Gadamer llama "la cosa del texto", sin un otro con el que podamos entrar en diálogo más que con el texto mismo, porque como afirmaba Unamuno lo que nos importa es lo dijo el autor y no su intención.

Dado que por un lado, la significación de un texto no necesariamente coincide con la intención de su autor, y sospechando por otro, que un texto dice más de lo que dice, 110 hay que considerar que un texto necesita de un lector. El texto se actualiza por medio de la lectura. Porque la fijación mediante la escritura, si bien da muerte a nuestro pensamiento, permite que otros puedan recrearlo y tomar vida a partir de él. 111

De esta manera, toda obra trasciende sus propias condiciones de producción y se abre a una serie ilimitada de lecturas situadas en contextos diferentes. "El texto", indica Ricoeur, debe poder descontextualizarse de la situación original para que se deje recontextualizar en otra situación mediante la lectura. 112

Con Ricoeur decimos, que con el análisis estructural, el texto tenía solamente un sentido (dimensión semiológica), pero ahora, con la lectura como interpretación apropiadora, tiene además una significación (dimensión semántica). De esta manera, la tarea que sigue es la de explicitar la suerte de ser-en-el mundo desplegado delante del texto. ${ }^{113} \mathrm{El}$ mundo del texto se convierte así en una trascendencia en la inmanencia de las estructuras, y tal trascendencia se produce a partir de que lo que Ricoeur denomina, variaciones imaginativas del mundo.

Notable es al respecto el recurso unamuniano a una terminología teatral. Unamuno sostiene que es por la "morcilla" por lo que sobreviviremos, 114 por lo que

pretación de lo no dicho, de lo que está oculto. (Cfr. Gadamer, H.G.: Verdad y Método, Salamanca, Sígueme, 1984, p. 409).

108 Unamuno, M. de: Tres novelas ejemplares y un prólogo, Op. cit., p. 20.

109 Ricoeur, P.: Temps et récit I, Paris, Seuil, 1983, p. 13 (citado por: Presas, M: Del ser a la palabra..., Op. cit.p. 82).

110 Cfr. Foucault, M.: Op. cit., pp. 33-34.

111 Unamuno, M. de: Cómo se hace una novela, Op. cit., pp. 14-15.

112 Ricoeur, P.: Del texto a la acción ..., Op. cit., p. 104.

113 Ricoeur, P.: Del texto a la acción ..., Op. cit., p. 51.

114 "[...] ¿sabe usted Avito, lo que es la morcilla? [...] morcilla se llama, [...] a lo que meten los actores por su cuenta en sus recitales, a lo que añaden a la obra del autor dramático [...]" (Cfr. Unamuno, M. de: Amor y Pedagogía, Op. cit., p. 54). 
el lector agregue, añada, a la obra. A partir de esto puede tener lugar la aplicación del texto a nosotros mismos (dimensión pragmática), ya que para la hermenéutica clásica, después de la comprensión, viene la aplicación. En este sentido el hombre no tiene ya una naturaleza prefijada, sino que se va haciendo, es un Homo faber, sólo existe lo que obra, ${ }^{115}$ y esta idea es posible porque hay un previo anonadamiento que proviene de la imaginación. 116

El hombre es capaz de refigurar imaginariamente un estado distinto del actual no quedándose en el "estado de yecto", de expósito, de arrojado, sino siendo "proyecto". En este sentido la novela puede orientar en la búsqueda del sentido de la existencia, porque para Unamuno la novela misma es pro-yecto.

¿Debemos quedarnos entonces en el momento de la comprensión? Si le hacemos esta pregunta a los textos de Unamuno, y si fuera posible a Unamuno mismo, la respuesta seguramente sería negativa ya que, para nuestro autor, lo vital es el para qué. ¿Para qué comprendernos a nosotros mismos? Decíamos antes que para la hermenéutica, como la entendían los clásicos, luego de la comprensión y de la interpretación culmina en la aplicación, en la que, como afirma Ricoeur, a partir del relato, el hombre se da cuenta de su propia historicidad, 117 y eso queda bien claro en Unamuno con En torno al casticismo.

Al respecto podemos observar cómo Unamuno enlaza en su concepción de la recepción, lectura y vida, literatura e historia: "[...] La historia, lo único vivo, es el presente eterno, el momento huidero que se quedan pasando, que pasa quedándose, y la literatura no es más que muerte. Muerte de que otros pueden tomar vida. ${ }^{118}$

La dimensión pragmática de la obra literaria se nos revela en Unamuno a través de la lectura que los vacíos del texto deja como indeterminados posibilitando, al actualizarlos, hacer de la novela nuestra propia novela, haciendo de los personajes, nuestro propio yo. Por ello dice Unamuno que: "[...] Y al decir que estoy para alumbrarme, con este -me no quiero referirme, lector mío, a mi yo solamente, sino a tu yo, a nuestros yos. Que no es lo mismo nosotros que yos." 119

Nuestro autor, en las páginas finales de la "Continuación" de Cómo se hace una novela, nos revela la respuesta: "[...] para qué se hace una novela? Para hacerse el novelista. [...] Para hacer al lector, para hacerse uno con el lector [...]" 120

En esta cita se pone de manifiesto lo que al comienzo de este parágrafo indicábamos a partir de la dedicatoria que hace en Amor y Pedagogía. La función de la obra como mediadora entre autor y lector, lleva a partir de la lectura a "hacer al lec-

\footnotetext{
115 Cfr. Unamuno, M. de: Tres novelas ejemplares y un prólogo, Op. cit., p. 16.

116 Presas, M.: Op. cit., p. 144.

117 Citado por Presas, M.: Op. cit., p. 125.

118 Unamuno, M. de: Cómo se hace una novela, Op. cit., pp. 14-15.

119 Unamuno, M. de: Cómo se hace una novela, Op. cit., p. 159.

120 Ibid., p. 157
} 
tor", pero al "hacer al lector" también se hace el autor con él. Esta cuestión se repite en el último apartado del prólogo/epílogo a la segunda edición de Amor y Pedagogía. Allí Unamuno cierra su introducción diciéndole al lector, que fue el lector quien lo fue haciendo a él mientras él hacía el texto y hacía al receptor, lector. Son sumamente significativas las dos últimas líneas de este prólogo/epílogo, ya que Unamuno, que firma como "El Autor" y no con su nombre, agradece al lector ofreciéndose con el corazón porque la obra pertenece al lector. ${ }^{121}$ ¿Qué significa este "hacer al lector" que mienta Unamuno en el fragmento citado? ¿Cómo se hace a un lector? Y ¿cómo se hace un autor?

[...] Nuestra obra es nuestro espíritu y mi obra soy yo mismo que me estoy haciendo día a día y siglo a siglo, como tu obra eres tú mismo, lector que te estás haciendo momento a momento [...] Cada uno es hijo de sus obras quedó dicho y lo repitió Cervantes, hijo del Quijote, pero ¿no es uno también padre de sus obras? Y Cervantes padre del Quijote. [...] $]^{122}$

Como lo prioritario para Unamuno es el para qué, en el tiempo de la narración se reconfigura el tiempo de nuestra vida, viéndola más claramente. Es este alumbramiento de nuestros yos al que se refería Unamuno. Como sostiene Presas, en la narración descubrimos ese orden subterráneo de la experiencia humana cuyo sentido se nos escapa en la confusión de la vida. ${ }^{123}$ Lo importante, dice Unamuno, es cómo acabará el lector. 124

Recordemos lo que unas líneas atrás decíamos acerca de la importancia del para qué en Unamuno. Y digamos con él que "[...] El Unamuno de mi leyenda, de mi novela, el que hemos hecho juntos mi yo amigo y mi yo enemigo y los demás, mis amigos y mis enemigos, este Unamuno me da vida y muerte, me crea y me destruye, me sostiene y me ahoga. [...]"125 Este Unamuno creado por él y por sus lectores, sus lectores serios y sus detractores, le permite eternizarse, y a la vez eternizarnos. Por ello, "El hombre de dentro, el intra-hombre [...] cuando se hace lector hácese por lo mismo autor, o sea actor. [...]"'126

Sartre sostenía en ¿Qué es la literatura? que escribir es pues a la vez revelar un mundo y proponerlo como una tarea a la generosidad del lector. ${ }^{127}$ ¿Y qué es sino

\footnotetext{
121 Cfr. Unamuno, M. de: Amor y Pedagogía, Op. cit., p. 22.

122 Unamuno, M. de: Cómo se hace una novela, Op. cit., p. 138.

123 Presas, M.: Op. cit., p. 81.

124 Cfr. Unamuno, M. de: Cómo se hace una novela, Op. cit., p. 120.

125 Ibid., Op. cit., p. 71.

126 Unamuno, M. de: Cómo se hace una novela, Op. cit., p. 141.

127 Sartre, J.P.: ¿Qué es la literatura?, Buenos Aires, Losada, 1976, p. 80 (citado por Presas, M.: Op. cit., p. 134).
} 
esto mismo lo que nos dice Unamuno al preguntarnos cómo acabaremos nosotros, lectores, al acabar la lectura si es que leemos comiendo?

[...] Y cómo acabarás tú, lector? Si no eres más que lector, al acabar tu lectura, y si eres hombre, hombre como yo, es decir: comediante y autor de ti mismo [... $]^{128} \mathrm{Y}$ sólo haciéndose uno el novelador y el lector de la novela se salvan ambos de su soledad radical. En cuanto se hacen uno se actualizan y actualizándose se eternizan. 129 [...] Si ellos me hacen pensar y hacerme en mi pensamiento - que es mi obra y mi acción- yo les hago obrar y acaso pensar. Y entre tanto ellos y yo vivimos. Y así es, lector, como se hace para siempre una novela. ${ }^{130}$

Así, el lector que lee una novela comiéndola está más preocupado por cómo acabará él que por cómo acabarán los personajes de ésta, abriendo de esta manera una dimensión pragmática, ético-política de la obra.

\section{Referencias bibliográficas}

Borges, J.L.: "El escritor argentino y la tradición”, en Carlos Frías (ed.), Obras Completas, Buenos Aires, Emecé, 1974, pp. 267-274.

CAStello Dubrá, J.: Diccionario etimológico de términos utilizados frecuentemente en educación, Buenos Aires, ed.vs.

Cerezo Galán, p. : Las máscaras de lo trágico. Filosofía y tragedia en Miguel de Unamuno, Madrid, Trotta, 1996.

CEREzo GALÁn, p. : "El vacío de la palabra. El nihilismo y la experiencia de la palabra en Miguel de Unamuno", en Chaguaceda Toledano, A. (ed.), Miguel de Unamuno, estudios sobre su obra, Vol. IV, Salamanca, Universidad de Salamanca, 2009, pp. 135-158.

Foucault, M.: Nietzsche, Freud, Marx, Buenos Aires, El cielo por asalto, s/f.

GadAmer, H.G.: Verdad y Método, Salamanca, Sígueme, 1984.

Gómez Miranda, R.: "Cinco puntos clave del pensamiento de Unamuno", Horizonte, Bello Horizonte, V.4, No7, 2005, pp. 51-75.

INGWERSEN, S.: "Unamuno and Schleiermacher: the "agonic style" and Protestant hermeneutics", Anglican Theological Review, Chicago, Vol.67, N³, 1985, pp. 260-272.

InSAUSTI UGARrizA, X.: "Unas pinceladas sobre la obra y la figura de Unamuno", Riev, 41, 1, 1996, pp. 35-52.

\footnotetext{
128 Unamuno, M. de: Cómo se hace una novela, Op. cit., p. 120.

129 Ibid., pp. 157-158.

130 Ibid., p. 144.
} 
LONGHURST, C.: "La tradición hermenéutica en la narrativa unamuniana", en Chaguaceda Toledano, A. (ed.), Miguel de Unamuno, estudios sobre su obra, Vol.IV, Salamanca, Universidad de Salamanca, 2009, pp. 349-361.

López Molina, A.: "Introducción”, en Unamuno, M., Del Sentimiento Trágico de la Vida, Madrid, Biblioteca Nueva, 2006, pp. 11-55.

Marcos, L.A.: Miguel de Unamuno: una filosofía hermenéutica española, Tesis Doctoral, Universidad de Salamanca, 1991.

Meyer, F.: La ontología de Miguel de Unamuno, trad. C. Goicoechea, Madrid, Gredos, 1962.

Padilla Novoa, M.: Unamuno: filósofo de encrucijada, Bogotá, Cincel, 1985.

PRESAS, M.: Del ser a la palabra. Ensayos sobre estética, fenomenología y hermenéutica, Buenos Aires, Biblos, 2009.

Ricoeur, P.: Del texto a la acción. Ensayos de Hermenéutica II, trad. P. Corona, Buenos Aires, FCE, 2001.

Ricoeur, P.: Tiempo y Narración II, trad. A. Neira, México, Siglo XXI, 2008.

Ricoeur, P.: Temps et récit I, Paris, Seuil, 1983.

Rossi, M.J.: "La hermenéutica y la investigación filosófica", http://hum.unne.edu.ar/revistas/postgrado/revista2/4_rossi.pdf, Universidad Nacional del Nordeste, s/f, pp. 1-6.

SARTRE, J.p. :¿Qué es la literatura?, trad. A. Bernárdez, Buenos Aires, Losada, 1976.

SCHLEIERMACHER, F.: Ermeneutica, Milano, Rusconi, 1996.

Unamuno, M. de: Obras Completas, Manuel García Blanco (ed.), Madrid, Editorial Escelice, Vol. I, III, VI, VII y VIII, 9 vols., 1966/67.

Unamuno, M. de: Cómo se hace una novela, Buenos Aires, Alba, 1927.

UnAmuno, M. de: Tres novelas ejemplares y un prólogo, Buenos Aires, Espasa Calpe, 1955.

Unamuno, M. de: Del Sentimiento Trágico de la Vida, Madrid, Biblioteca Nueva, 2006.

Unamuno, M. de: Amor y pedagogía, Buenos Aires, Espasa Calpe, 1952.

Unamuno, M. de: Niebla, Buenos Aires, Espasa Calpe, 1993.

Unamuno, M. de: En torno al casticismo, Madrid, Alianza, 1986.

Gastón Beraldi

Facultad de Filosofía y Letras

Universidad de Buenos Aires

gberaldi@filo.uba.ar 